\title{
APLIKASI METODE VALUE ENGINEERING DALAM PENENTUAN ALTERNATIF FASILITAS RUMAH DI PERUMAHAN
}

\section{Ilyas Mas'udin}

\section{ABSTRACT}

Every Real Estate Developer want the houser built wanted by customers. Ther is a dicrease in sale of houses that be saled by Tegalgondo Asri developer caused customer's unsatisfaction in fasilities or import of sevise value given by developer to customers who lived there. One of alternative to rise design value vasilities is making a new fasility design better than the old one.

To find a new fasility design we need data that is from observation, interview and spreading questionnaires to costomers or developers, that are : Current fasility design data, Criterial value data, Feasibility data, Profit last data, applied design cost data and evaluation data.

Best fasility design alternative can be faund using work plan steps of value engineering sucg as : Information step, kreatif step, analysis of fasility design alternatives step, developing step and recommendation of best design fasility alternative step. According to those five (5) step conclude. That the best fasility design value is 1,186 and increasing the best fasility design value than the old one is about $18,6 \%$

\section{Kata kunci :, Design alternatives, performans, Cost, Value}

\section{PENDAHULUAN}

Kebutuhan manusia akan rumah dari waktu ke waktu kian meningkat.Pada mulanya rumah hanya sekedar untuk keperluan melindungi diri terhadap pengaruh alam saja, selanjutnya rumah berkembang sesuai dengan kebudayaan manusia yang dilatarbelakangi beberapa aspek, seperti aspek sosial,kultur budaya,dan ekonomi. Rumah dicipta tidak sekedar memenuhi kebutuhan pokok manusia, melainkan juga sebagai cermin citra penghuninya.

Upaya mengembangkan idea rumah berjalan terus, sehingga terciptalah hal-hal baru yang belum terpikirkan sebelumnya.
Hakekat rumah bagi penghuni, kaitan rumah dengan lingkungan sekitarnya dan keseimbangan alam sekeliling perumahan maka akan terwujud sentuhan manusiawi,sentuhan alami yang sesuai dengan citra penghuninya. Terwujudnya segala ide tersebut akan memberikan pesona tersendiri bagi para pemandang yang menikmati pesona penampilan rumah tersebut.

Pelayanan suatu perumahan sangat berpengaruh terhadap kepuasan konsumen. Salah satunya dapat dilakukan dengan pemenuhan kebutuhan fasilitas rumah yang diinginkan konsumen. Apabila fasilitas rumâh yang tersedia tidak sesuai dengan kebutuhan 
konsumen, maka konsomen akan mencari perumahan lain yang menyediakan fasilitas seperti yang mereka inginkan. Kejadian diatas akan berkurangnya jumlah atau minat konsumen dan ini sangat merugikan pihak perusahaan.Dan apabila perusahaan dapat menekan biaya dan menaikkan performansi produknya, otomatis banyak konsumen yang tertarik.

\section{TINJAUAN PUSTAKA}

\section{Prinsip Dasar Rekayasa Nilai}

Rekayasa nilai mempunyai tujuan untuk mendapatkan nilai (value) semaksimal mungkin. Sedangkan value dinyatakan dengan memperbandingkan performansi dengan biaya sebagai berikut :

$$
\text { VALUE }=\frac{\text { PERFORMANSI }}{\text { BIAYA }}
$$

Sebaiknya produk dianggap tidak baik apabila tidak ada kesesuaian antara performasi yang diberikan dengan biaya yang dikeluarkan.

Ada beberapa usaha untuk meningkatkan nilai, aantara lain:

1. Menurunkan biaya dan performansi, dimana penurunan performansi lebih kecil dibandingkan dengan penurunan biaya ( $\mathrm{G}$ ).

2. Performansi tetap biaya diturunkan $(\mathrm{H})$.

3. Performansi naik biaya diturunkan (I).

4. Performansi naik biaya tetap ( L ).

Menaikkan performansi dan biaya, dimana kenaikan performansi lebih besar dibandingkan kenaikan biaya ( $\mathrm{O}$ ).

\section{Rencana Kerja Rekayasa Nilai}

Ada berbagai macam job plan dalam pelaksanaan rekayasa nilai antara lain :

1. Environmental Protection Agency (EPA)

2. Six Phase Job Plan

3. Standard Five Phase Job Plan

4. General Services Administration (GSA)

5. Eight Phase Job Plan

Prosedur yang baisanya dipakai adalah Standard Five Phase Job Plan yang terdiri dari tahapan berikut :

1. Tahap Informasi (Information Phase)

2. Tahap Kreatif (Creative Phase)

3. Tahap Analisa (Judgment Phase)

4. Tahap Pengembangan (Development Phase)

5. Tahap Rekomendasi ( Recommendation Phase).

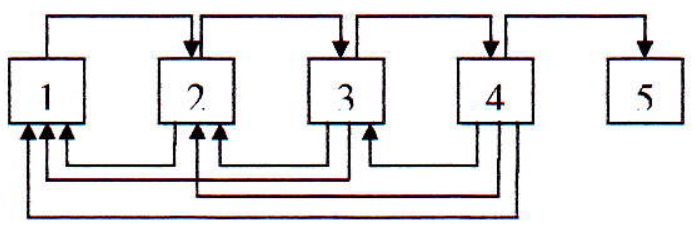

Gambar 1. Hubungan antar fase dalam rencana kerja lima tahapan rekayasa nilai

Teknik-Teknik Yang Digunakan :

\section{Metode FAST}

FAST merupakan penggambaran secara sistematis dari fungsi-fungsi. FAST adalah suatu kumpulan metode pemeriksaan proses yang rumit dan menentukan tahap demi tahap fungsi yang dibutuhkan. Diagram FAST diterapkan untuk serangkaian fungsi yang saling berhubungan dengan fungsi yang lain.Dalam industri konstruksi, FASTdigunakan untuk menentukan fungsi- 
fungsi proyek dan juga fungsi dari tiap komponen proyek.

Tujuan dari FAST adalah untuk menyederhanakan rancangan, operasi, rencana. prosedur atau masalah kedalam elemen-elemen fungsi yang dapat diidentifikasikan. Tiap rangkaian fungsi dievaluasi keefektifannya dan kegunaanya dengan harapan penghilangan, modifikasi atau pengurangan fungsi-fungsi. Semua fungsi-fungsi dapat di identifikasikan sebagai penggambaran dua kata kerja dan kata benda.

\section{Proses Hierarki Analitik (PHA)}

Proses Hierarki Analitik ini pertama kali dikembangkan oleh seorang ahli matematika Thomas L Saaty. Teknik pengambilan keputusan ini banyak digunakan secara luas diseluruh dunia. Didalam buku Pengambilan Keputusan Bagi Para Pemimpin dinyatakan bahwa teknik ini menangani dengan sukses kasus-kasus dalam banyak persoalan pengambilan keputusan.

Didalam memecahkan persoalan proses hierarki analitik menggunakan tiga prinsip yaitu :

1. Prinsip menyusun hierarki

2. Prinsip menyusun prioritas

3. Prinsip konsistensi logis

\section{Analisa Morfologis}

Analisa morfologis memecahkan suatu masalah menjadi elemen-elemen, kemudian mengidentifikasikannya sejumlah alternatif atribut untuk setiap elemen dan menyusun alternatif pemecahan dengan megkombinasikan atribut-atribut dari setiap elemen yang berbeda-beda.

\section{Analisa Kebutuhan}

Analisa kebutuhan adalah aktifitas dalam menganalisa kebutuhan untuk dapat menghasilkan spesifikasi desain. Spesifikasi desain merupakan gabungan dari constrain sehingga menghasilkan suatu analisa yang lengkap.

Dalam analisa kebutuhan digunakan suatu teknik, yaitu analisa atribut (analisa adjective) yang bertujuan untuk menghasilkan keterkaitan antar adjective (sifat) yang ada pada suatu produk dan mengidentifikasikan sifat-sifat yang kurang maupun yang berlebihan dari produk yang direncanakan dengan cara sumbang saran (brainstroming)

\section{METODOLOGI PENELITIAN}

Metode yang digunakan dalam studi Rekayasa Nilai adalah menggunakan prosedur Standart Job Plant yang terdiri dari:

\section{Fase Informasi (Information Phase)}

Dalam fase ini segala macam informasi tentang fasilitas perumahan yang diperlukan untuk studi rekayasa nilai dikumpulkan. Fase ini meliputi:

Survey perusahaan

* Identifikasi data / kebutuhan yang diperlukan 
Penyebaran kuesioner untuk
mendapatkan kriteria dan bobot
berdasarkan kriteria.

\section{Analisa Kebutuhan}

Hasil yang didapat dari atribut masing-masing diberi bobot atau nilai yang sesuai dengan hasil penyebaran kepada para responden adalah :

- Biaya Pengadaan

- Kesesuaian Bentuk

- Kenyamanan

- Keindahan
- Layout

- Tingkat Kegunaan

\section{ANALISA DAN PEMBAHASAN}

\section{Tahap Kreatif}

Pada tahap ini akan akan dibangkitkan sebanyak mungkin alternatif pemecahan masalah, dalam hal ini pemenuhan fasilitas pelayanan. Berdasarkan elemen fasilitas yang disediakan oleh perumahan IKIP Tegal Gondo Asri maka dapat dirumuskan alternatif-alternatif desain usulan

Tabel 1

Desain Awal dan Alternatif Desain Usulan

\begin{tabular}{|c|c|c|}
\hline Komponen & Desain Awal & Desain Usulan \\
\hline Tempat Ibadah & 1 buah Masjid & $\begin{array}{l}\text { Disediakan luas tanah dan konsumen yang } \\
\text { akan menentukan: } \\
\text { * luas tanah } 10 \times 10 \mathrm{~m}^{2} \\
\text { * luas tanah } 10 \times 15 \mathrm{~m}^{2} \\
\text { * luas tanah } 20 \times 20 \mathrm{~m}^{2}\end{array}$ \\
\hline Keamanan & $\begin{array}{l}\text { Pos keamanan didepan dengan } \\
\text { jendela dari kaca dan penjagaan } \\
\text { malam oleh } 2 \text { orang Satpam }\end{array}$ & $\begin{array}{l}\text { * Pos kemanan kecil didepan dengan } \\
\text { penjagaan siang }+2 \text { orang Satpam } \\
\text { * Pos keamanan kecil didepan dengan } \\
\text { penjagaan siang + malam oleh satu orang } \\
\text { Satpam dan ronda tiap malam oleh } \\
\text { masyarakat perumahan. }\end{array}$ \\
\hline Fasilitas Air & Sumur Pompa & $\begin{array}{ll} & \text { PDAM } \\
\text { * Sumur Arthesis }\end{array}$ \\
\hline Layanan Kebersihan & $\begin{array}{l}\text { Tempat sampah dari karet dengan } \\
1 \text { orang tukang sampah }\end{array}$ & $\begin{array}{l}\text { * Tempat sampah dari kayu + } 2 \text { orang } \\
\text { tukang sampah } \\
\text { * Tempat sampah dari batu bata }+1 \text { orang } \\
\text { tukang sampah }\end{array}$ \\
\hline Sarana OR & $\begin{array}{l}\text { Satu lapangan Sepak Bola ukuran } \\
\text { kecil }\end{array}$ & $\begin{array}{l}\text { *apangan Bolla Volley } \\
\text { * Lapangan Tennes. }\end{array}$ \\
\hline Balai Pertemuan & Balai RW & $\begin{array}{l}\text { * Disediakan Aula } \\
* \quad \text { Disediakan Pos Kamling }\end{array}$ \\
\hline Tempat Bermain & & $\begin{array}{ll}\text { * Disediakan Taman } \\
\text { * Disediakan Taman Kanak-Kanak ( TK ) }\end{array}$ \\
\hline
\end{tabular}

Desain-desain usulan diatas merupakan hasil wawancara dengan pihak konsumen mengenai apa yang sebenarnya diinginkan dan dibutuhkan konsumen. Dengan demikian, alternatif desain sistem fasilitas perumahan akan diperoleh dengan cara mengkombinasikan setiap alternatif desain diatas. 
Mengingat banyaknya jumlah hasil kombinasi alternatif desain yang diperoleh, maka alternatif-alternatif desain tersebut disusun dalam bentuk usulan tunggal. Alternatif-alternatif dalam bentuk usulan tunggal tersebut dapat dilihat pada tabel 2 berikut ini

\section{: Tahap Analisa}

Pada tahap ini akan dilakukan penilaian terhadap alternatif-alternatif desain yang telah berhasil dimunculkan pada tahap kreatif, yaitu pada tabel 5.2 dan penilaian yang akan dilakukan adalah :

\section{Analisa Keuntungan dan Kerugian. \\ 2. Analisa Matriks Kelayakan. \\ 3. Analisa Matriks Evaluasi.}

\section{Analisa Keuntungan Dan Kerugian}

Analisa ini merupakan langkah pertama untuk memastikan bahwa hanya alternatif-alternatif desain yang benar-benar memiliki manfaat bagi peningkatan nilai pelayanan / penyediaan fasilitas diperumahan IKIP Tegal Gondo Asri yang akan diperhitungkan pada analisa selanjutnya, sehingga akan mengarah pada tujuan yang akan dicapai.Faktor-faktor tersebut adalah:

\section{Biaya Pelaksanaan.}

Adalah total biaya yang harus dikeluarkan untuk penerapan suatu alternatif desain.

\section{Penghematan yang Diperoleh.}

Merupakan nilai penghematan yang diperoleh dari penerapan suatu alternatif desain baru jika dibandingkan dengan desain awalnya.

\section{Kepuasan Konsumen.}

Adalah seberapa besar konsumen merasa puas terhadap alternatif desain yang dinilai, dengan mempertimbangkan keluhan-keluhan konsumen terhadap sistem pelayanan pengadaan fasilitas.

\section{Kenyamanan Konsumen.}

Adalah sampai sejauh mana tingkat kenyamanan yang mampu diberikan oleh penerapan suatu alternatif desain.

\section{Kemudahan Pelaksanaan.}

Adalah tingkat kemudahan pelaksanaan suatu alternatif desain yang dinilai

\section{Analisa Matriks Kelayakan}

Analisa ini bertujuan untuk menilai seberapa jauh alternatif desain yang ditawarkan dapat diimplementasikan sehubungan dengan kriteria-kriteria penilaian yang telah ditetapkan. Penilaian terhadap setiap alternatif desain dilakukan dengan memberikan skor antara $1-10$, criteria tersebut antara lain: Biaya pelaksanaan, Kemungkinan pelaksanaan, Daya Serap pasar, kepuasan konsumen dan penghematan yang diperoleh.

\section{Analisa Matriks Evaluasi.}

Pada analisa Matriks Evaluasi, alternatif-alternatif desain harus dikombinasikan. Berdasarkan Analisa Kelayakan, didapat 108 buah kombinasi alternatif desain, dan jumlah itu masih terlalu banyak untuk dianalisa dalam Matriks Evaluasi 


\section{Analisa Performansi Alternatif Desain}

Hasil penilaian Matriks Evaluasi dan

Bobat-Bobot Kriteria dari Analytical Hierarchy Process ( AHP ) pada Bab sebelumnya, selanjutnya akan digunakan untuk menghitung performansi setiap alternatif desain usulan termasuk desain awalnya.

\section{Tahap Pengembangan}

Pada tahap pengembangan terdapat dua hal yang akan dilakukan yaitu :

\section{Perhitungan biaya implementasi,}

yaitu untuk menentukan besarnya biaya yang diperlukan bagi penerapan suatu alternatif desain.

2. Penentuan nilai (Value), yaitu menentukan nilai akhir dari alternatifalternatif desain terpilih dan desain awalnya. Nilai (Value) diperoleh dengan menghitung perbandingan antara alternatif desain dengan biaya operasional yang dibutuhkan.

\section{Perhitungan Nilai.}

Berdasarkan pada performansi dan biaya penerapan alternatif-alternatif desain, maka akan dilakukan perhitungan nilai (Value) dari penyediaan fasilitas dari masing-masing alternatif desain

\section{Analisa Pembahasan}

Dari tahap informasi yang hasilnya sudah didapatkan kemudian masuk ke tahap analisa yang terdiri atas:

Maka dari itu bagi kegiatan pengembangan selanjutnya,yang harus dilakukan adalah mengalokasikan sumber dana yang ada agar lebih optimal. Ini berarti untuk alternatif usulan yang sekiranya tidak memerlukan perbaikan dari desain awal akan dikeluarkan dari pertimbangan. Disini alternatif yang dikeluarkan dari pertimbangan berdasarkan wawancara dengan pihak pengembang adalah untuk elemen Tempat Ibadah dan Balai Pertemuan. Sehingga alternatif-alternatif desain hasil Analisa Keuntungan dan Kerugian adalah sebagai berikut:

Tabel 4

Desain Awal dan Alternatif Desain Usulan Sebagai Hasi Analisa Keuntungan dan Kerugian

\begin{tabular}{|c|c|}
\hline Alternatif & Deskripsi Komponen \\
\hline $\begin{array}{c}0 \\
(\text { Awal })\end{array}$ & $\begin{array}{l}\text { a. Tempat Ibadah berupa satu buah Masjid } \\
\text { b. Pos keamanan didepan dengan jendela kaca dan penjagaan malam oleh } \\
2 \text { orang Satpam } \\
\text { c. Fasilitas air berupa sumur Pompa } \\
\text { d. Tempat sampah dari karet }+1 \text { orang tukang sampah } \\
\text { e. Sarana OR berupa satu lapangan sepak bola ukuran kecil } \\
\text { f. Balai pertemuan berupa balai RW. }\end{array}$ \\
\hline 4 & $\begin{array}{l}\text { Pos penjagaan kecil didepan dengan penjagaan siang oleh } 2 \text { orang } \\
\text { Satpam. }\end{array}$ \\
\hline 5 & $\begin{array}{l}\text { Pos penjagaan kecil didepan dengan penjagaan siang dan malam oleh } 1 \\
\text { orang Satpam dan ronda tiap malam oleh masyarakat perumahan. }\end{array}$ \\
\hline 6 & Fasilitas air disediakan PDAM \\
\hline 7 & Fasilitas air disediakan sumur Arthesis \\
\hline
\end{tabular}




\begin{tabular}{|c|l|}
\hline 8 & $\begin{array}{l}\text { Layanan kebersihan adalah tempat sampah dari kayu ditambah 2 orang } \\
\text { tukang sampah. }\end{array}$ \\
\hline 9 & $\begin{array}{l}\text { Layanan kebersihan tempat sampah dari batu bata ditambah satu orang } \\
\text { tukang sampah. }\end{array}$ \\
\hline 10 & Sarana Olah Raga adalah satu lapangan bola volley. \\
\hline 11 & Sarana Olah Raga adalah satu lapangan tennes. \\
\hline 14 & Tempat bermain berupa taman \\
\hline 15 & Tempat bermain berupa Taman Kanak-Kanak ( TK ) \\
\hline
\end{tabular}

\section{Analisa Matriks Kelayakan}

Berdasarkan criteria yang ada yaitu: criteria A (Biaya Pelaksanaan), Kriteria B (Kemungkinan Pelaksanaan), Kriteria C
(Daya Serap Pasar), Kriteria D (Kepuasan Konsumen) dan Kriteria E (Penghematan yang diperoleh) kemudian dibuat rangking peniliaan matriks kelayakan sebagai beriku

Tabel 5

Ranking Penilaian Matriks Kelayakan

\begin{tabular}{|c|c|c|c|c|c|c|c|c|}
\hline \multirow[t]{2}{*}{ No } & \multirow[t]{2}{*}{ Alternatif } & \multicolumn{5}{|c|}{ Kriteria } & \multirow[t]{2}{*}{ Total } & \multirow[t]{2}{*}{ Ranking } \\
\hline & & A & B & C & D & E & & \\
\hline 1 & 0 & 74 & 62 & 58 & 55 & 70 & 319 & $9^{*}$ \\
\hline 2 & 4 & 61 & 62 & 63 & 57 & 66 & 309 & 11 \\
\hline 3 & 5 & 74 & 73 & 69 & 68 & 66 & 350 & $3^{*}$ \\
\hline 4 & 6 & 65 & 74 & 71 & 70 & 72 & 352 & $1^{*}$ \\
\hline 5 & 7 & 64 & 59 & 58 & 58 & 71 & 310 & 10 \\
\hline 6 & 8 & 67 & 68 & 71 & 70 & 67 & 343 & $4^{*}$ \\
\hline 7 & 9 & 63 & 63 & 65 & 64 & 71 & 326 & $8^{*}$ \\
\hline 8 & 10 & 71 & 70 & 73 & 68 & 69 & 351 & $2^{*}$ \\
\hline 9 & 11 & 73 & 64 & 62 & 59 & 70 & 328 & $7^{*}$ \\
\hline 10 & 14 & 65 & 69 & 71 & 70 & 65 & 340 & $5^{*}$ \\
\hline 11 & 15 & 64 & 65 & 68 & 66 & 66 & 329 & $6^{*}$ \\
\hline
\end{tabular}

\section{Analisa Performansi Alternatif Desain}

Hasil penilaian Matriks Evaluasi dan

Bobat-Bobot Kriteria dari Analytical

Hierarchy Process ( AHP ) pada sebelumnya, selanjutnya akan digunakan untuk menghitung performansi setiap alternatif desain usulan termasuk desain awalnya, seperti terlihat pada berikut

Tabel 6

Penilaian Performansi Pada Matriks Evaluasi

\begin{tabular}{|c|c|c|c|c|c|c|c|c|}
\hline \multirow{3}{*}{$\begin{array}{c}\text { Alternatif } \\
\text { (Bobot) }\end{array}$} & \multicolumn{6}{|c|}{ Kriteria } & \multirow{3}{*}{ Total } & \multirow{3}{*}{ Rank } \\
\hline & BP & LO & TK & KB & KYM & KID & & \\
\hline & 0,2497 & 0,1401 & 0,0751 & 0,0470 & 0,2802 & 0,2079 & & \\
\hline \multirow[t]{2}{*}{0} & 29 & 24 & 30 & 25 & 26 & 25 & & \\
\hline & 7,2413 & 3,3624 & 2,2530 & 1,1750 & 7,2852 & 5,1975 & 26,5144 & 9 \\
\hline \multirow[t]{2}{*}{1} & 33 & 32 & 34 & 33 & 33 & 34 & & \\
\hline & 8,2401 & 4,4832 & 2,5534 & 1,5510 & 9,2466 & 7,0686 & 33,1429 & $1^{*}$ \\
\hline \multirow[t]{2}{*}{ II } & 28 & 29 & 28 & 34 & 34 & 33 & & \\
\hline & 6,9916 & 4,0629 & 2,1028 & 1,5980 & 9,5268 & 6,8607 & 31,1428 & $3^{*}$ \\
\hline \multirow[t]{2}{*}{ III } & 25 & 31 & 27 & 30 & 32 & 34 & & \\
\hline & 6,2425 & 4,3431 & 2,0277 & 1,4100 & 8,9664 & 7,0686 & 30,0583 & 4 \\
\hline \multirow[t]{2}{*}{ IV } & 24 & 29 & 26 & 31 & 33 & 32 & & \\
\hline & 5,9928 & 4,0629 & 1,9526 & 1,4570 & 9,2466 & 6,6528 & 29,3647 & 6 \\
\hline \multirow[t]{3}{*}{$\mathrm{V}$} & 32 & 31 & 32 & 33 & 33 & 30 & & \\
\hline & 7,9904 & 4,3431 & 2,4032 & 1,5510 & 9,2466 & 6,2370 & 31,7713 & $2^{*}$ \\
\hline & & & & & & & & \\
\hline
\end{tabular}




\begin{tabular}{|c|c|c|c|c|c|c|c|c|}
\hline VI & 29 & 28 & 29 & 32 & 32 & 29 & & \\
\hline & 7,2413 & 3,9228 & 2,1779 & 1,5040 & 8,9664 & 6,0291 & 29,8415 & 5 \\
\hline VII & 25 & 29 & 27 & 30 & 33 & 30 & & \\
\hline & 6,2425 & 4,0629 & 2,0277 & 1,4100 & 9,2466 & 6,2370 & 29,2267 & 7 \\
\hline VIII & 24 & 28 & 26 & 31 & 32 & 28 & & \\
\hline & 5,9928 & 3,9228 & 1,9526 & 1,4570 & 8,9664 & 5,8212 & 28,1128 & 8 \\
\hline
\end{tabular}

\section{Peningkatan Performansi}

\section{Alternatif Desain Terpilih Terhadap}

\section{Desain Awalnya}

Peningkatan performansi alternatifalternatif desain terpilih al ( alternatif I, alternatif $\mathrm{V}$, dan alternatif II ) terhadap desain awal, yaitu:

Tabel 7

Peningkatan Performansi Alternatif Desain Terpilih Terhadap Desain Awalnya

\begin{tabular}{|c|c|c|c|}
\hline No & Alternatif & $\begin{array}{c}\text { Performansi } \\
(\mathbf{P})\end{array}$ & $\begin{array}{c}\text { Peningkatan } \\
\text { Performansi } \\
(\mathbf{P})\end{array}$ \\
\hline 1 & 0 (awal) & 26,5144 & \\
\hline 2 & I & 33,1429 & $24,9996 \%$ \\
\hline 3 & V & 31,7713 & $19,8266 \%$ \\
\hline 4 & II & 26,5144 & $17,4562 \%$ \\
\hline
\end{tabular}

Implementasi Biaya

Biaya-biaya yang harus dikeluarkan dari penerapan alternatif desain tersebut adalah (dalam jumlah total) :

1. Biaya pengadaan Masjid :

Rp. 150.000.000,-

2. Pos keamanan desain awal :

Rp. $\quad 5.000 .000$,-

3. Pos keamanan desain usulan :

Rp. $\quad 3.000 .000,-$

4. Sumur pompa : Rp. 155.200.000,-

5. PDAM : Rp. 271.600.000,-

6. Tempat sampah karet :

Rp. 6.790.000,-

7. Tempat sampah kayu :

Rp. $\quad 3.880 .000$,-

8. Tempat sampah batu bata :

Rp. 6.790.000,-
9. Lapangan sepak bola terbuka $20 \times 30 \mathrm{~m}^{2}$ :Rp. 60.000.000,-

10. Lapangan bola volley $6 \times 12 \mathrm{~m}^{2}$ :

Rp. $\quad 9.200 .000$,-

11. Balai RW : Rp. $6.000 .000,-$

12. Taman: Rp. 2.500.000,-

13. Taman Kanak-Kanak (TK)

Rp. 8.000.000,-

Total unit rumah yang akan dibangun sebanyak 520 unit

\section{A. Desain Awal}

\begin{tabular}{|l|l|l|}
\hline No & \multicolumn{1}{|c|}{ Uraian } & \multicolumn{1}{c|}{ Biaya } \\
\hline 1 & $\begin{array}{l}\text { Tempat Ibadah satu buah } \\
\text { Masjid }\end{array}$ & Rp. 386.600,- \\
\hline 2 & $\begin{array}{l}\text { Pos Keamanan didepan } \\
\text { dengan jendela kaca }\end{array}$ & Rp. 12.900,- \\
\hline 3 & Sumur Pompa & Rp. 400.000,- \\
\hline 4 & Tempat Sampah karet & Rp. 17.500,- \\
\hline 5 & $\begin{array}{l}\text { Lapangan sepak bola } \\
\text { terbuka }\end{array}$ & Rp. 154.700,- \\
\hline 6 & Balai RW & Rp. $15.500,-$ \\
\hline \multicolumn{2}{|c|}{ Total } & Rp. 987.200,- \\
\hline
\end{tabular}

B.Alternatif I (Ranking I)

\begin{tabular}{|c|l|lc|}
\hline No & \multicolumn{1}{|c|}{ Uraian } & \multicolumn{2}{c|}{ Biaya } \\
\hline 1 & $\begin{array}{l}\text { Tempat Ibadah Berupa } \\
\text { Masjid }\end{array}$ & Rp. 288.462,- \\
\hline 2 & $\begin{array}{l}\text { Pos Keamanan kecil } \\
\text { didepan }\end{array}$ & Rp. & $5.770,-$ \\
\hline 3 & PDAM & Rp. & $700.000,-$ \\
\hline 4 & Tempat sampah kayu & Rp. $10.000,-$ \\
\hline 5 & Lapangan Bola Volley & Rp. & $17.693,-$ \\
\hline 6 & Balai RW & Rp. & $11.539,-$ \\
\hline 7 & Taman & Rp. & $4.808,-$ \\
\hline \multicolumn{2}{|c|}{ Total } & Rp. 1.038.272,-- \\
\hline
\end{tabular}

C. Alternatif V ( Ranking II)

\begin{tabular}{|c|c|c|}
\hline No & Uraian & Blaya \\
\hline 1 & $\begin{array}{l}\text { Tempat Ibadah Berupa } \\
\text { Masjid }\end{array}$ & Rp. 288.462,- \\
\hline 2 & $\begin{array}{ll}\text { Pos Keamanan kecil } \\
\text { didepan }\end{array}$ & Rp. $\quad 5.770,-$ \\
\hline 3 & PDAM & Rp. $700.000,-$ \\
\hline 4 & Tempat sampah kayu & Rp. $10.000,-$ \\
\hline 5 & Lapangan Bola Volley & Rp. $17.693,-$ \\
\hline 6 & Balai RW & Rp. $11.539,-$ \\
\hline 7 & Taman Kanak-Kanak & Rp. $\quad 15.385$ \\
\hline \multicolumn{2}{|r|}{ Total } & Rp. 1.048.849,- \\
\hline
\end{tabular}




\section{Alternatif II ( Ranking III )}

\begin{tabular}{|l|l|lr|}
\hline No & Uraian & Biaya \\
\hline 1 & Tempat Ibadah Berupa Masjid & Rp. & $288.462,-$ \\
\hline 2 & Pos keamanan kecil didepan & Rp. & $5.770,-$ \\
\hline 3 & PDAM & Rp. & $700.000,-$ \\
\hline 4 & Tempat sampah batu-bata & Rp. & $17.500,-$ \\
\hline 5 & Lapangan Bola Volley & Rp. & $17.693,-$ \\
\hline 6 & Balai RW & Rp. & $11.539,--$ \\
\hline 7 & Taman & Rp. & $4.808,-$ \\
\hline \multicolumn{2}{|l|}{ Total } & Rp. & $\mathbf{1 . 0 4 5 . 7 7 2 , -}$ \\
\hline
\end{tabular}

\section{Perhitungan Nilai.}

Dari penyediaan fasilitas dari masing-masing alternatif desain ( Desain Awal, Alternatif I, Alternatif $\mathrm{V}$, dan Alternatif II ). Sedangkan untuk pengkonversian dari performansi menjadi rupiah adalah sebagai berikut

Hasil Perhitungan Nilai ( Value ) Fasilitas Perumahan

\begin{tabular}{|c|c|c|c|c|c|c|}
\hline No & Alternatif & $\mathbf{P}_{\mathbf{n}}$ & $\mathbf{C}_{\mathbf{n}}$ & $\mathbf{V}$ & $\begin{array}{c}\text { Peningkatan } \\
(\mathbf{\Delta} \mathbf{v})\end{array}$ & Rank \\
\hline 1 & 0 (Awal) & 26,5144 & 987.200 & 1 & & 4 \\
\hline 2 & I & 33,1429 & 1.038 .272 & 1,189 & $18,9 \%$ & $1^{*}$ \\
\hline 3 & V & 31,7713 & 1.048 .849 & 1,128 & $12,9 \%$ & 2 \\
\hline 4 & II & 31,1428 & 1.045 .772 & 1,109 & $10,9 \%$ & 3 \\
\hline
\end{tabular}

Ternyata alternatif desain usulan yang menghasilkan peningkatan nilai fasilitas perumahan terbesar adalah alternatif $\mathbf{I}$.

\section{KESIMPULAN}

Setelah melakukan Studi Rekayasa Nilai untuk meningkatkan nilai pelayanan/pengadaan fasilitas di perumahan IKIP Tegal Gondo Asri maka dapat disimpulkan :

1. Desain awal fasilitas perumahan IKIP Tegal Gondo Asri sebelum dilakukan perbaikan adalah :
a. Tempat Ibadah satu buah Masjid.
b. Pos Keamanan didepan dan penjagaan malam oleh 2 orang Satpam.
c. Fasilitas Air adalah sumur pompa

d. Layanan kebersihan adalah tempat sampah dari karet +1 tukang sampah

e. Sarana olah raga berupa satu lapangan sepak bola terbuka

f. Balai pertemuan berupa Balai RW

2. Desain usulan terbaik tentang fasilitas perumahan diperumahan IKIP Tegal Gondo Asri setelah dilakukan perbaikan adalah :

a. Tempat Ibadah satu buah Masjid

b. Pos keamanan kecil didepan dan penjagaan siang + malam oleh 1 orang Satpam dan ronda tiap malam oleh masyarakat perumahan

c. Fasilitas air adalah PDAM

d. Layanan kebersihan adalah tempat sampah kayu +2 orang tukang sampah 
e. Sarana Olah raga berupa lapangan bola Volley

f. Balai pertemuan berupa Balai RW

g. Tempat bermain berupa Taman

3. Alternatif desain terbaik adalah Alternatif I ( satu ) dengan performansi sebesar 33,1429 dan peningkatan performansi Alternatif I (satu) jika dibandingkan terhadap desain awal adalah $24,9996 \%$.

4. Nilai desain fasilitas Alternatif I (satu) adalah sebesar 1 dan nilai desain usulan terbaik sebesar 1,189 sehingga peningkatan nilai pelayanan Alternatif $\boldsymbol{I}$ (satu) jika dibandingkan terhadap desain awal adalah $18,9 \%$.

\section{DAFTAR PUSTAKA}

Info Bisnis, 1996, Bisnis Properti Anjlok Menjelang Pemilu 1997, Edisi 38, 15 - 29 Okt / Tahun ke - II.
Budiharjo Eko, 1984, Arsitektur dan Kota di Indonesia, Penerbit Alumni Bandung,

Tjiptono Fandi, 1996, Manajemen Jasa, Penerbit Andi Offset, yogyakarta.

Budihardjo Eko, , 1987, Percikan Masalah Arsitektur, Perumahan, Perkotaan, Gajah Mada University Press.

Zimmerman W. Larry, Value Engineering A Pratical Approach For Owner, Designer, and Contractor, CBS Publishar and Distributors.

Miles, Lawrences D, 1972, Technique of Value Analisis and Engineering, New York : McGraw- Hillbook Company, Second Edition.

O'Brien, James J, 1976, Value Analysis in Design and Contruction New York McGraw-Hillbook Company.

Sudjana, 1996, Metoda Statistika, Penerbit Tarsito Bandung, Edisi Ke-6, 